\title{
The teaching of English vocabulary through pictorial reading texts and games to a group of primary school students in
}

\section{East Jakarta}

\author{
Anna Marietta da Silva \\ Universitas Katolik Indonesia Atma Jaya, Indonesia \\ anna.silva@atmajaya.ac.id
}

\begin{abstract}
This community service is a free English tutorial for a group of primary schools' students aged ten years old residing in Duren Sawit, East Jakarta and its surroundings. The program is part of a bigger tutorial program called Bimbingan Belajar Mita (Bimbel Mita) conducted by a non-profit organization that was initiated by the Maria Clarist congregation sisters around eight years ago. The participants of the six-month program were ten students. The method of the community service was teaching the basic English vocabulary through pictorial short English texts and vocabulary games. The former technique was used for the first half of the semester and the latter for the second half of the period. During the tutorial, the students have acquired a number of the targeted English nouns related to objects in the house, garden, animals, colors, professions, fruits, vegetables; verbs related to daily activities at home and adjectives related to descriptions of objects and human beings and some adverbs. In learning the English vocabulary, they show more enthusiasm for games rather than the pictorial reading texts.
\end{abstract}

\begin{abstract}
Absrak Kegiatan pengabdian kepada masyarakat yang diselenggarakan oleh penulis berbentuk tutorial bahasa Inggris gratis untuk sekelompok murid sekolah dasar berusia sekitar sepuluh tahun yang tinggal di Duren Sawit, Jakarta Timur dan sekitarnya. Program tutorial ini merupakan bagian dari program tutorial yang diselenggarakan oleh Bimbingan Belajar Mita (Bimbel Mita) yang didirikan oleh sebuah organisasi non-profit dengan diinisiasi oleh para suster Kongregasi Maria Claris pada sekitar delapan tahun lalu. Peserta kegiatan pengabdian kepada masyarakat yang berdurasi enam bulan ini berjumlah sepuluh orang siswa. Kesepuluh siswa ini diberikan pengajaran kosakata bahasa Inggris dasar. Teknik pengajaran yang digunakan ialah pengajaran melalui teks bacaan bergambar dalam bahasa Inggris dan permainan kosakata. Teknik pertama digunakan selama tengah semester pertama dan teknik kedua selama tengah semester berikutnya. Selama tutorial ini para peserta telah memperoleh sejumlah kata benda, misalnya terkait objek di rumah, kebun, hewan, warna, profesi, buah-buahan, sayuran; kata kerja terkait kegiatan sehari-hari di rumah; dan kata sifat yang menggambarkan sifat benda dan deskripsi manusia. Dalam pembelajaran para peserta tampak lebih antusias belajar menggunakan permainan dibandingkan dengan teks bergambar berbahasa Inggris.
\end{abstract}

Keywords: vocabulary; reading text; games; tutorial; community service

\section{ठ OPEN ACCESS}

Citation: da Silva, A.M. (2020). The teaching of English vocabulary through pictorial reading texts and games to a group of primary school students in East Jakarta. Riau Journal of Empowerment, 3(1), 1-15. https://doi.org/10.31258/raje.3.1.1-15

Paper type: Community service

Received: 2019-07-04 Revised: 2020-01-18 Accepted: 2020-03-03

Language: English (en)

ISSN 2623-1549 (online), 2654-4520 (print)

(c) 2020 Anna Marietta da Silva. Author(s) retain the copyright of article published in this journal, with first publication rights granted to Riau Journal of Empowerment. The article is licenced under Creative Commons Attribution 4.0 International License. This license permits unrestricted use, distribution, and reproduction in any medium, provided the original author and source are credited. 


\section{INTRODUCTION}

It has been widely accepted that the mastery of vocabulary is the key to learning the English language (Smith \& Murphy, 2015). Naturally, vocabulary is acquired through daily interactions with the speakers of the language, for instance, the family members, the peers, the teachers and/or the neighbors. However, such situation is hardly present in the context of English learning in Indonesia where children commonly learn English at schools. English is learnt mostly in formal contexts through the English teacher's explanation in the classroom and English textbooks. It is then very challenging for young Indonesian children to acquire a lot of vocabularies in order to be able to use English fluently, especially when reading (English texts) is not part of the children's routines although lately media such as television, internet and games have been considered to be the sources from which today's generation acquire the English words (Puimège \& Peters, 2019).

Reading English texts may not be a habit for most Indonesian young students. Knowing that reading is beneficial (from teachers, parents, families, peers or other sources) is not always parallel to the willingness and eagerness to read (Iftanti, 2012). The researcher found that students mostly read English texts because they were assigned and not because they enjoyed reading. That may indicate students only read texts in their English textbooks and do not have wide access to other types of English texts at the school libraries (note that the context is Indonesian national schools). It may also be the case that they read texts other than textbooks at home, in the bookstore or on the internet (if they have access to the internet on their parents' or their cellphones). However, the reading activities are based upon teachers' instruction.

The ability to read and understand the English texts may be closely related to one's vocabulary (Graves et al., 2018; Li \& Kirby, 2015; Pellicer-Sánchez, 2016). However, it is common knowledge that it is hard for students to understand a text because of his low vocabulary knowledge. For the low-level learners, acquiring the 2000 most frequently used words used in English may be sufficient to understand a simple reading text. Yet, higher-level students need to learn not only the high-frequency but also the low-frequency words in-depth. In other words, they need to learn not only the single meaning of the English words and how to pronounce them, but also the synonyms, the multiple meanings, and the collocations. The researchers suggested that teachers' scaffolding in various reading activities and texts are important.

The various reading activities to acquire the English vocabulary may range from reading pictorial short stories, tales or biographies to a variety of vocabulary games. Games have been proven to be interesting and effective for acquiring English and increasing their motivation to learn the language (Alfirević, 2015; Chou, 2012). Some important notes to remember when giving games to students include the "... easy-to-follow rules and procedures that can be clearly communicated and remembered by all players" (Wells \& Narkon, 2011). Bingo, Crossword, and Hangman are a few examples of common vocabulary games for young children. Given that the enjoyment of vocabulary learning may stem from the reading activities and doing fun games, I intentionally designed one English tutorial that can enable students to learn the most frequently used English vocabulary through reading texts and vocabulary games.

The tutorial was held in Bimbingan Belajar Mita or Bimbel Mita that is conducted by a non-profit organization that was initiated by one of Maria Clarist congregation sisters, $\mathrm{Sr}$. Yovita, MC because of the urge from the mother-scavengers to have Math and English teachers for their children (Joko Tri Sukarso, personal communication, February 17, 2019). Bimbel Mita was established on March 11, 2010, and since then has consistently provided free 
of charge Math and English tutorials to primary up to junior high school students every Sunday from 10.00 to 11.30 all through the year, except during the fasting month, Lebaran, Easter and Christmas holidays and the picnic day (Maria Theresia Wijaya, personal communication, February 17, 2019). At first, the program focuses on free education for children of less fortunate families around Duren Sawit, East Jakarta. However, due to the students' and parents' words of mouth, more participants come from other areas such as Pondok Kelapa, Pondok Bambu and Bekasi. There are two groups of students: primary and junior high school students. The first group is further divided into Grade 1, Grade 2, Grade 3, Grade 4, Grade 5 and Grade 6. The second is further categorized into Grade 1,2 and 3. Eight to ten teachers are present every week at Bimbel Mita. Most of them teach Math. Only two teach English. Some teachers are retirements and some other university students. The purpose of this community service English tutorial program was to develop the primary students' English vocabulary acquisition.

\section{METHOD}

The method of this community service program was English vocabulary tutorial or teaching. The tutorial was free of charge and conducted from January to July 2019 to a group of grade 3 primary school students of several state schools in Duren Sawit, East Jakarta. Picture 1 provides an illustration of the learning situation at Bimbel Mita (I was standing in front of the small whiteboard on the right corner). All the teachers have helped teaching voluntarily. I volunteered myself to the committee in December 2018 and started teaching on January 19, 2019. Table 1 describes the list of readings and games during the English tutorial I gave.

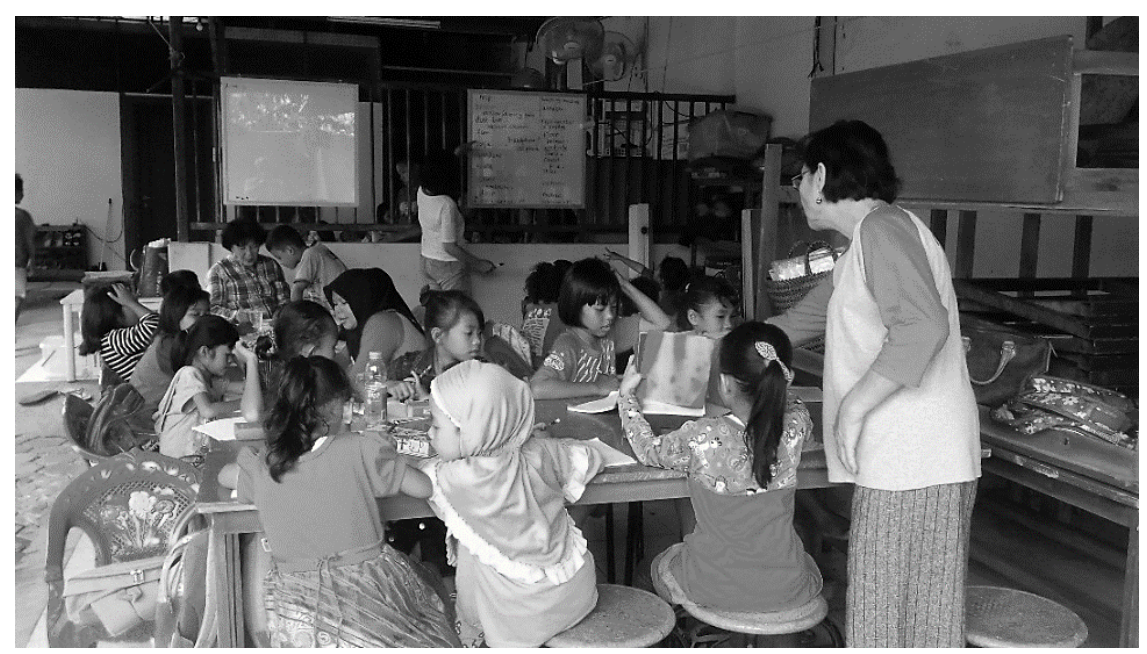

Picture 1. Learning situation at Bimbel Mita

Table 1. List of readings during the reading tutorial

\begin{tabular}{cll}
\hline Week & Title of books, texts, or games & \multicolumn{1}{c}{ Sample vocabularies } \\
\hline $1-2$ & A Packet of Seeds (Lee, 1997a) & Nouns: seed, stem, bud, packet, hole \\
& & Verbs: give, dig, wait, water, cover \\
$3-4$ & Our New House (Lee, 1997b) & $\begin{array}{l}\text { Nouns: drawer, house, bathroom, door, fan, light, } \\
\text { suitcase, stair, wall, work } \\
\end{array}$ \\
& & Adjective: tired \\
& Quantifiers: many, much \\
\hline
\end{tabular}




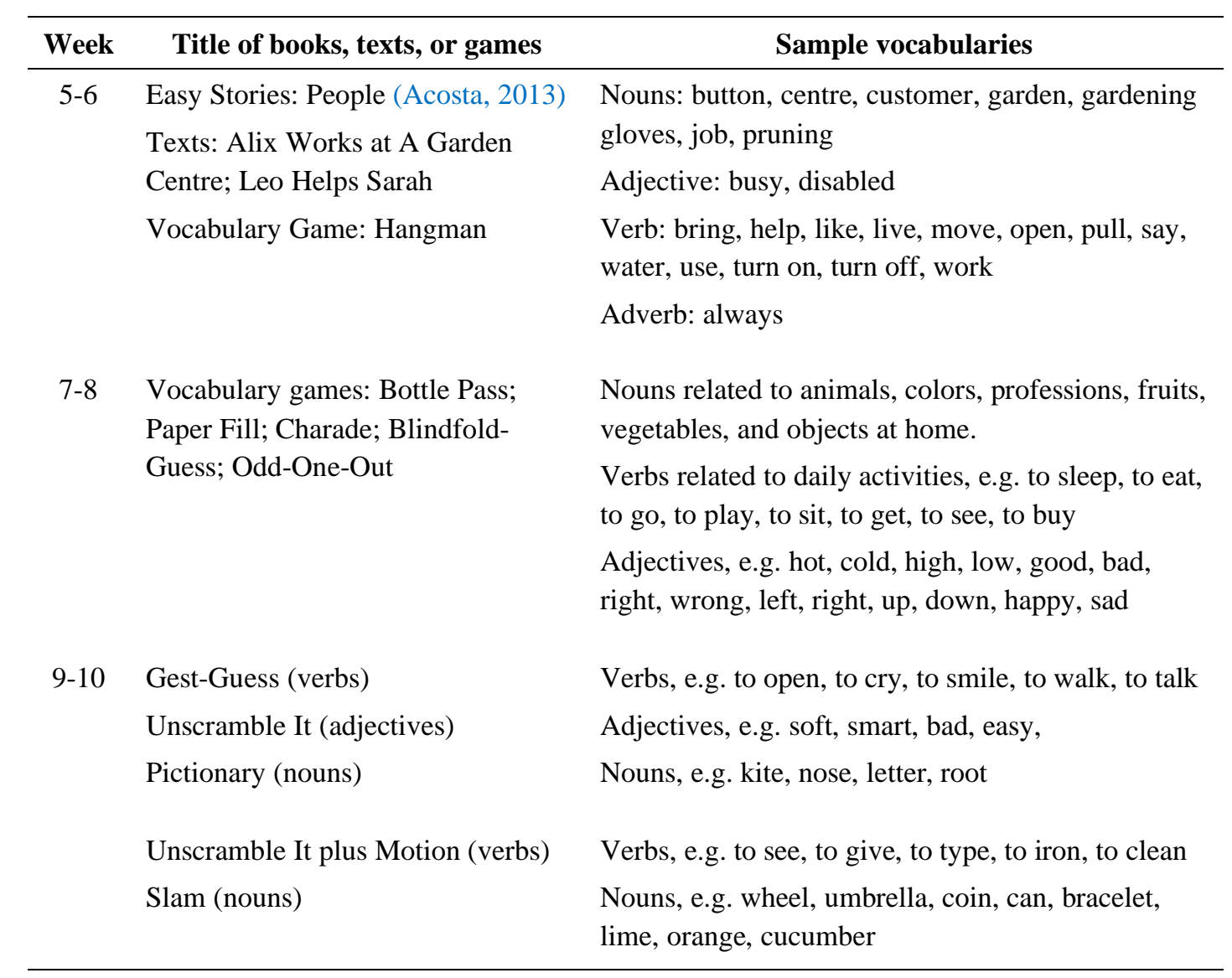

\section{RESULTS AND ACHIEVEMENTS}

I intentionally brought several storybooks with pictures to my first tutoring. As far as I know, it is not easy for English teachers to emphasize English reading skills in common classrooms in Indonesian primary schools, especially for Grade 3. I also suspected that most Indonesian students, including those studying in state schools, do not read English story books. At first, I intended to give simultaneous Extensive Reading sessions. However, after knowing that the students had never read English storybooks prior to the English tutoring lessons, I changed my plan into learning vocabulary through reading pictorial story books and playing games. I expected that while absorbing the vocabulary and knowing basic vocabularies of English, I can guide them to Extensive Reading sometime in the fourth month. I used Indonesian mixed with English throughout the lessons to give instruction, to explain new words and to explain the questions I gave. In all the meetings, I mostly used Indonesian though we had our selfintroduction in English. My students were able to utter English greetings like good morning, goodbye and thank you. They also knew some basic vocabularies related to house, school and families.

In the first week, I got them to read a pictorial storybook titled "A Packet of Seeds." The story was about a girl growing seeds into plants. Each page consisted of one picture and one to two simple sentences. In the first meeting, knowing that they did not know much words in the storybook, the students quickly requested to learn the vocabularies first. They were ready with books and pens or pencils in their hands. So, after reading them a whole story, I got each of them reading the story aloud and asked them what the story was about. They were allowed to use the Indonesian language. My primary goals were to establish their reading skills, including reading a story as a unity, getting the main idea of the story and introducing them to 
new vocabularies and sentences in English. In addition, I wanted them to listen to their English pronunciation and feel how it is to pronounce English words. Therefore, I corrected their pronunciations only whenever necessary.

In the second week, I checked whether or not the students still remembered the story they read last week and learned the vocabularies they had got in the previous week. Since two new students were joining the lesson, I asked the old two students to retell the point of the story to their friends in Indonesian, but they were allowed to mix Indonesian and English. They inserted the words seed and packet into their explanation. After that, the two new students asked to copy their friends' vocabulary notes. While they were copying the notes, I had a guessing game to the other two. I asked them to mention the English words for the Indonesian words I said. I took all the words from A Packet of Seeds. One of the two new students finished her note-taking fast and joined the game. After that, they had a 10' break, and we started with the new reading, i.e. Our New House. However, as a pre-reading activity, I requested them to draw five to ten objects in their house on a piece of paper (see Picture 2). I would like to introduce some vocabularies first before they read the second storybook. Two could finish and submitted their pictures a few minutes before the class ended at 11.30. The other two asked to finish theirs at home and bring them the following week. I planned to get my students make their own pictorial glossaries from the collection of vocabulary pictorial sheet they make.

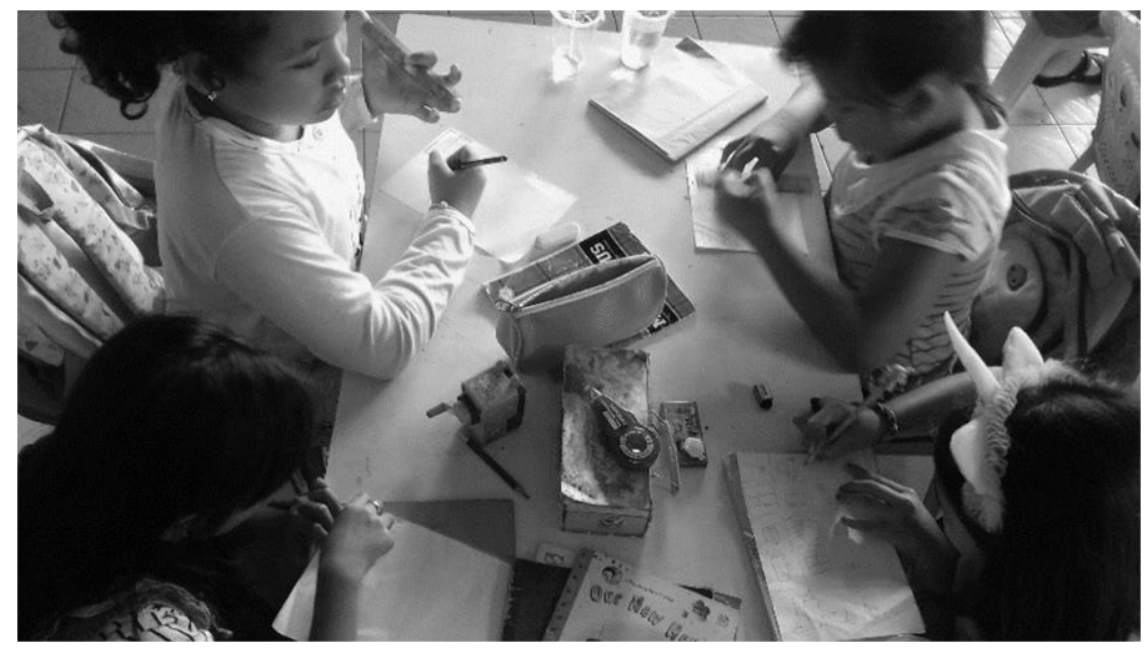

Picture 2. Students made pictorial glossaries

In the third week, students colored their pictures and named each object that was available in their house (see Picture 3), which was related to the second text, Our New House. The objects they drew included television, cellphone, gas stove, broom, mop, vacuum cleaner, door, window, wardrobe, curtain, washing machine, sofa, table, chair, refrigerator, aircondition, plant, fan, umbrella, and mattress. It turned out that they have learned the names of the objects at home at school. However, they did not remember the names of every object that they had learned. So, I wrote a list of the English words on the whiteboard and point at the word each time they ask the English word for the object they drew and colored. Then, I got them to remember each word they drew. Students were eager to have a guessing game as in the previous week, so to check their memory I had another guessing game with them. 


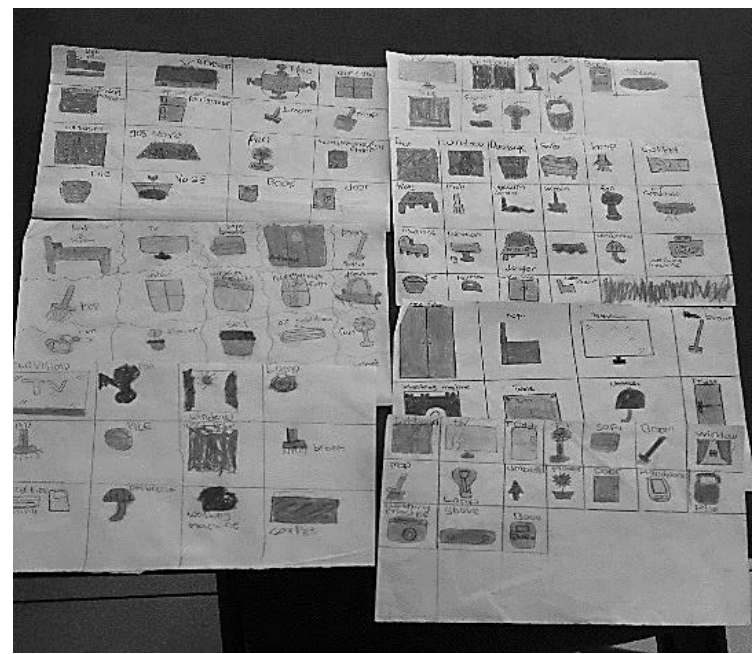

Picture 3. Students' objects-in-the-house pictorial glossaries

In the fourth week, I let students choose which activity they wanted to have. I first showed that they were going to discuss one short article about gardening, which is related to the first text they had in the first week, A Packet of Seeds. However, three of them asked to draw animals and color the animals. I saw that the objects they wished to learn are related to nature, which is part of knowledge in the first text, so I let them draw animals (see their pictures in Picture 4) while ensuring myself that they would ask for the English words of the animals. One student said she could not draw well, so I told them I would Google search a link of the animal cartoon to help them draw the animals comfortably. As I predicted, in the middle of their drawing, they asked for the names of the animals such as bee, elephant, snake, lizard, bird, butterfly, pig, and mouse. They liked and enjoyed the activity. I thought that that was the time when they could freely decide what they wished to learn, something that they may not get from school everyday as almost everything have been decided by the teacher and the school, for example, the materials and learning methods.

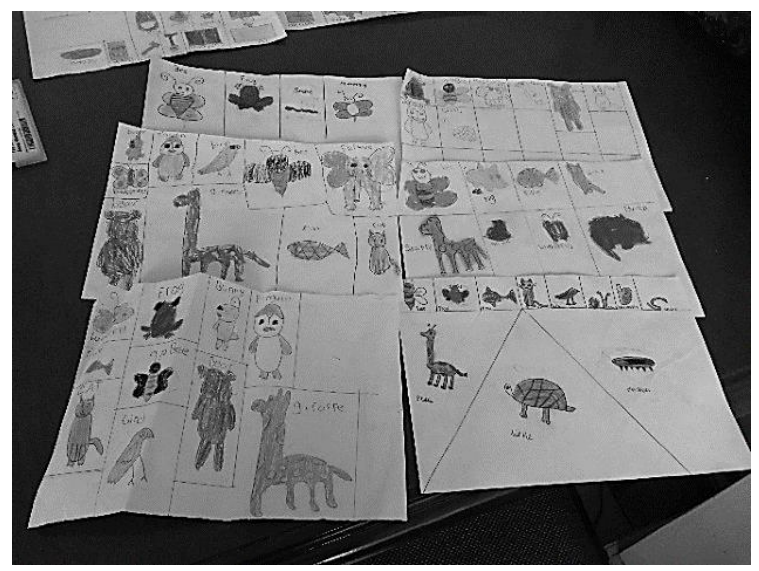

Picture 4. Students' animal pictorial glossaries

In the fifth week, I introduced them to two texts, i.e. Alix Works at A Garden Centre and Leo Helps Sarah. The former was related to the first text, but in this text, students learned new nouns, verbs and adjectives (see Table 1). The latter was related to the activity in the fourth week, drawing animals. The text tells students about a service dog named Leo, who helped a disabled girl, Sarah. I introduced a concept which may be new to them, i.e. the use of certain 
animals to help people with disabilities. The two texts are provided with short worksheets on vocabularies, which students did (see Picture 5).

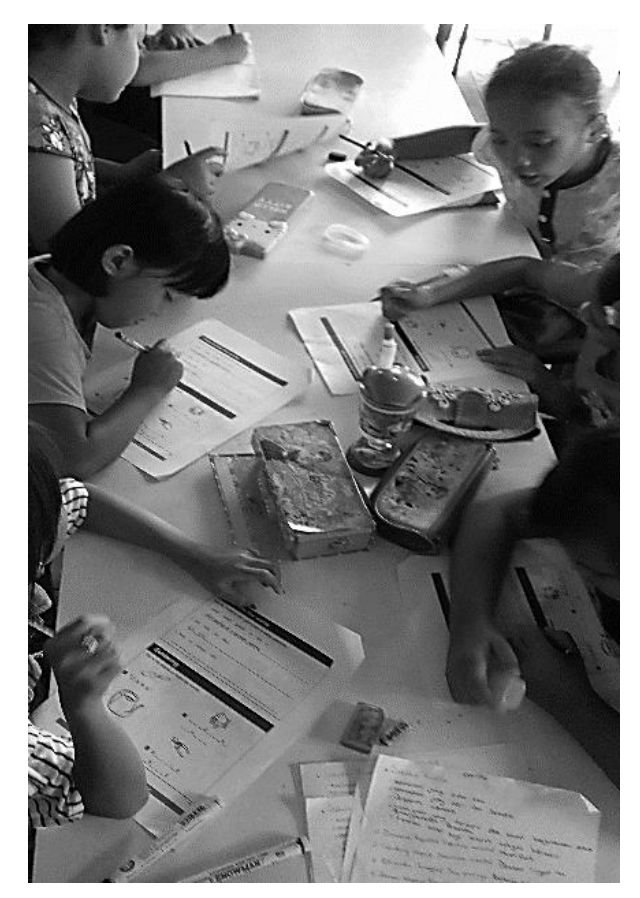

Picture 5. Students did a worksheet related to texts given in the fifth and sixth weeks

In addition, students enthusiastically asked for games to help them memorize the words for the following week, instead of merely writing the words and memorize them. So, in the sixth week, I provided several games. The first game was a 'noun' translation game similar to what I gave them in the third week. Yet, this time, the material was taken from the picture vocabulary on objects in the house they created. In that game, I mentioned the Indonesian nouns and students had to say the English words. One score was given for those who could give a correct answer. The second game was a 'verb' guessing game in which students had to guess orally the verb that I physically practice, for instance, to sleep, to eat, to drink, to see, to hear, to open, and to close. The third game was a 'noun' guessing game. In that game, students had to guess the names of several real objects (that are commonly available at home) I took from a purse and showed them, such as ear-rings, necklace, bracelet, glue, button, ball, stapler, highlighter, mirror, and pin. As a reward, I permitted each student to choose one realia and take it home. Because some students mistakenly pronounced some words such as [pil] for pile, [map] for mop, [bel] for ball, and [ker] for chair. Finally, students asked me to include nouns related to families, fruits and animals to the 'noun' translation game.

In the sixth week, because students had asked me to have a game, I had them play Hang Man. I knew the game when I was in junior high school, but I also checked ESLKidstuff.com to find other games. Yet, for this meeting, I chose that game since it was suitable for a fun vocabulary learning, and I had a mere guess that they had not played it before. My guess was right. So, first, I gave them a short but clear explanation on the rule of the game in English, which I then translated into Indonesian. After that, I tried out two words (apple and floor) for the game. The students were enthusiastic and straightly asked for their turn (see Picture 6). Each then had a turn to play it while others took a turn to guess the letter. I arranged their turns (three seconds for each student to guess one letter) and wrote their scores. I was surprised to find out that they had not memorized the English vowels and consonants. Consequently, I modeled the pronunciation of each alphabet in English and got them to say it to the player. 
Students guessed words that they had before and after the lessons with me, such as chair, sun, horse, rabbit, and walrus. They were delighted to play the game and asked for another game for the following meetings.

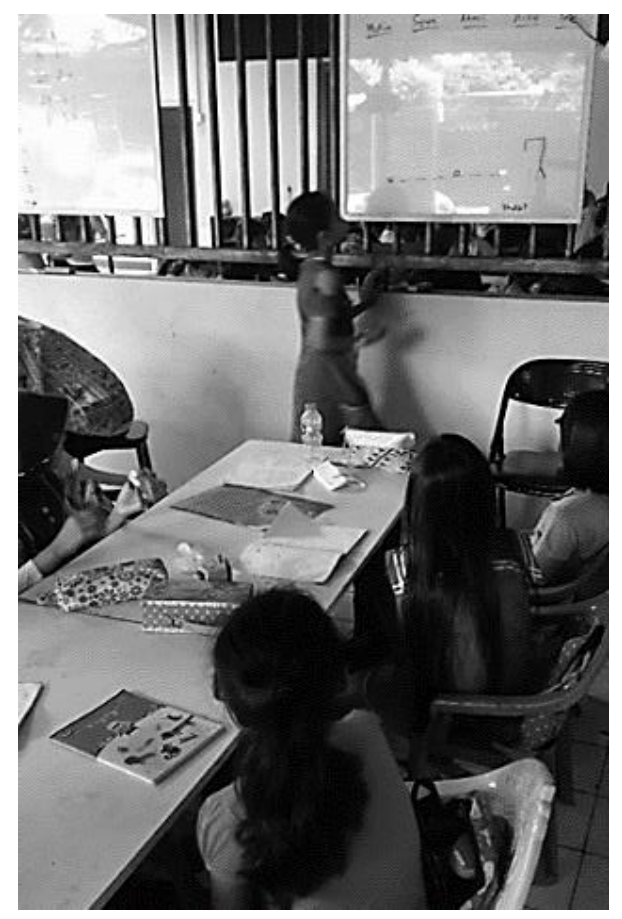

Picture 6. One student took a turn playing Hangman

In the seventh week, as requested by the students, I had them played several vocabulary games. I adapted a game named Apple Pass into Bottle Pass that was taken from the same website. Then I created another game that I call Paper Fill. Finally, I adopted the Charade game. Before the game was played, I gave a specific instruction, first in English, then in Indonesian. The reason for using the two languages was to ensure students could play the game. Only one or two students could understand the instruction I said in English, so I had to repeat it in Indonesian. In the first game, students had to throw an empty mineral bottle to her friend who had to catch the bottle and say one word in English in line with the theme mentioned before. First, I gave an example, where I mentioned the instruction, for example, "mention the name of a color" and threw one bottle to a student who had to say one color in English. Then I asked her to throw the empty bottle to another friend who had to catch the bottle and say another color. The trial game went on until everyone got their turns. Each right word was equal to one score and students were not allowed to repeat words that had been said by others. After everybody understood the rules, I started the game. Both students and I suggested themes for the game, i.e. animals, fruits, vegetables, profession, things in the house, and any objects. They enjoyed the game, wanted to compete among themselves and looked happy.

The next game was Paper Fill. I created the game based on I Spy game. While in the latter the teacher can say "I spy with my little eye something that begins with B" and students have to guess the object, in the former I had students write the words in a piece of paper. So, I had prepared several pieces of origami paper (so that student could have colorful paper, indeed, they were enthusiastic just picking up the paper) that I cut into triangle shapes. In this game students had to write words as I instructed, for instance, "write an English word that begins with b". First, as an example, I had them write two words in Indonesian on the blank triangle 
shape paper (see Picture 7). Next, they had to fold the paper and collected them to me. Then I had each of them pick up the collected paper so that everyone would not get theirs. After that, I had them speak the English versions of the two words written on the paper they had. Each correct answer deserved one point.

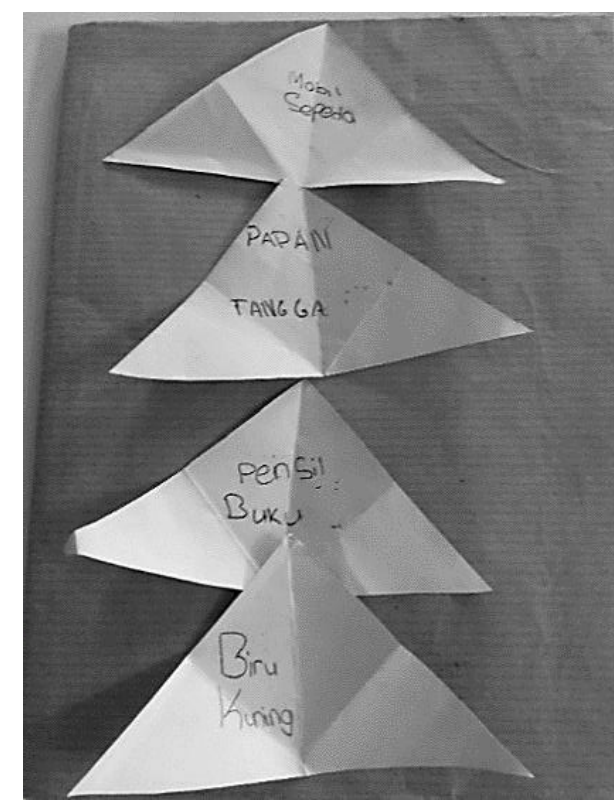

Picture 7. Some triangle-shaped paper with Indonesian words for Paper Fill game

As everyone understood the game, I distributed another triangle shape blank paper and had the students write five words as follows: (1) anything that is naturally red, (2) anything that is naturally green, (3) something liquid, (4) something sweet, and (5) something sour (see Picture 8). Again, after saying the instruction in English, I had to say it in Indonesian. Words such as liquid, natural and sour were new to students. Then, everyone read their answers, while I gave each correct answer one point. One student, A, always outperformed her friends in the two games.

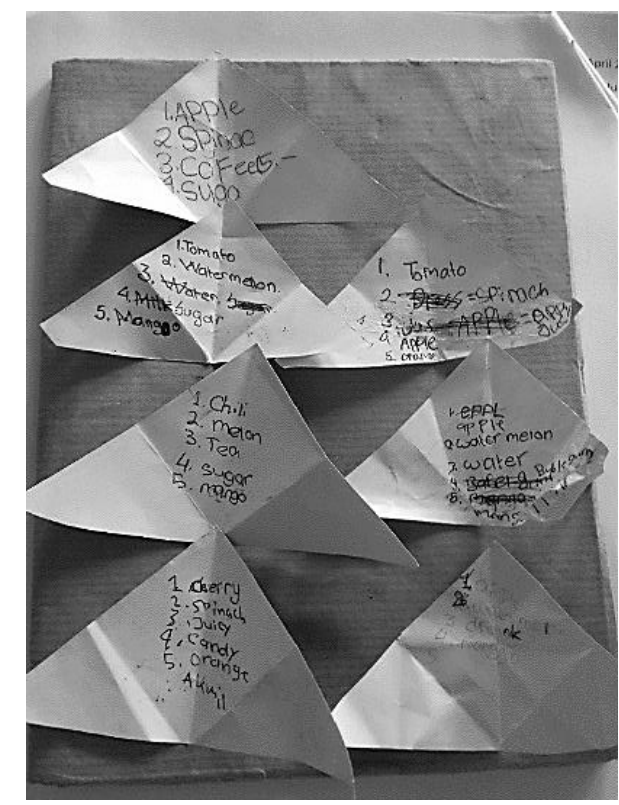

Picture 8. Some triangle-shaped paper with English words for Paper Fill game 
Finally, I had them play Charade in which I divided them into two groups (each group consisted of three persons) and had another student, $\mathrm{R}$, to listen to a sentence I whispered. This one student had to whisper the same sentence to each group. Unfortunately, it was approaching the end of the class, so the game was terminated until after $\mathrm{R}$ whispered to the first persons of each group (E and $\mathrm{S}$ ) who then whispered to the second person. However, I could see that the sentence I gave "Can I buy some ice cream and cookies?" was unfamiliar to the three of them. Perhaps, they had not learned the form at school before.

In the eight weeks, I had the students play three games: Charade, Blindfold-Guess and Odd-One-Out. All of the games were taken from the previously mentioned website. The first game was played in the previous week, but the students could only have one turn because the class was over. As I learned that most of had not been familiar with sentences yet, I gave isolated verbs such as to eat, to sit, to play and adjectives, such as happy, sad, fast. I noticed that they were familiar with nouns, but not verbs and adjectives. I divided them into two groups, each of which had three members and asked them to stand in a line. The first person had to listen to my whisper; then he or she had to whisper the word to the second person, who had to whisper the same word to the last person, who had to write the word whispered on the whiteboard. The right word deserved one point. As I predicted, what they wrote showed that they had not learned much verbs and adjectives. Most of the words were written based on how they say them in Indonesian. For instance, they wrote to gow for to go, to it for to eat, ap for up. Hence, upon checking the words written, I also taught the correct spellings and the Indonesian translations for the target words.

In the second game, the Blindfold-Guess, each student was blindfolded in turn. All still sat in their group. The others who had not got their turn were asked to pick up one object from a small fabric container containing several objects. After that, each gave the object to their blindfolded mate who had to say the name of the object in English. Each student got two turns. The objects that were used were not put back into the container.

Table 2. Several sets of words for the Odd-One-Out game

\begin{tabular}{ccccc}
\hline Set & \multicolumn{3}{c}{ Words } \\
\hline 1. & pink & yellow & dog & green \\
2. & horse & whale & cat & book \\
3. & bear & bird & ant & buffalo \\
4. & elbow & hand & nail & eye \\
5. & shorts & skirt & ball & shirt \\
6. & milk & burger & tea & coffee \\
7. & candy & bean & tomato & potato \\
\hline
\end{tabular}

In the last game, the Odd-One-Out, I wrote 14 sets of words on the board (while students had a break). Each set consisted of four words, and one of the four words did not belong to the same category of the other three (see the example in Table 2). Students took a turn to cross that odd word out (see Picture 9). Before playing the game, I gave an oral example to them in English and Indonesian first. Students liked the game and even asked to write their own set of words after they were done with the first turn (see Picture 10). 


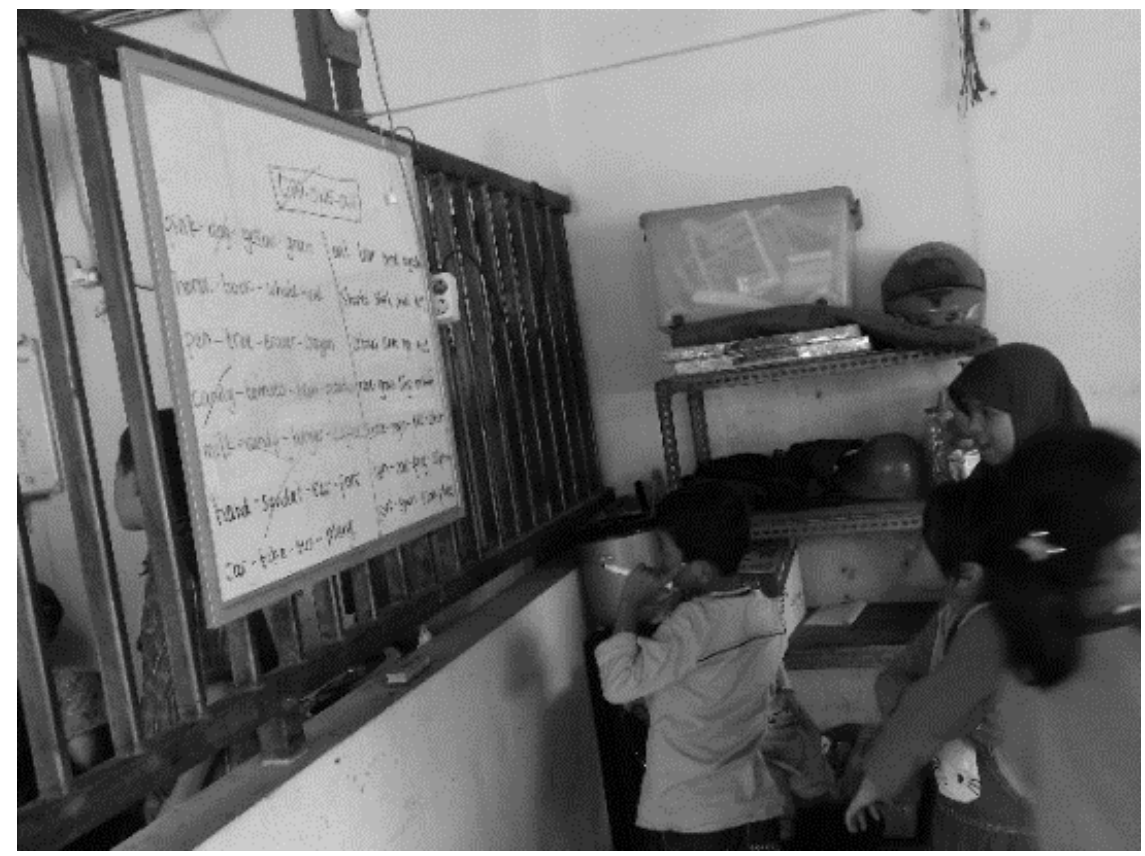

da Silva

11

Picture 9. Students took turn to play the Odd-One-Out game

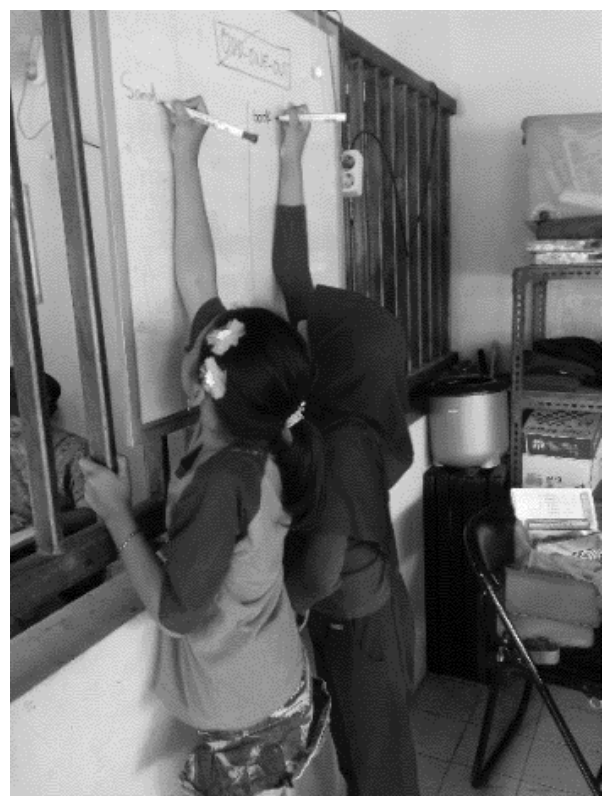

Picture 10. Students wrote their sets of word for the Odd-One-Out game

During the ninth week, I gave three vocabulary games, namely Gest-Guess, Unscramble It and Pictionary. The last two games were also taken and adapted from ESLKidsStuff.com (ESL Kidstuff, 2019). The first game is actually a shortened form that I created for Gesture-Guess, which focused on the common English verbs. This is not a new game. In the game students (in groups of 3) had to guess the English verbs of several motions that I acted out (see Table 3). In the second, game I wanted the students to learn the English adjectives. Hence, they had to unscramble a number of English adjectives on the board (see Table 4). In the last game, one student representing his/her group had to draw a word shown and had the group member guess the word (see Table 5). The words are nouns which are related to the human body, stationary, animal, house, kitchen, clothes, and plants. Not all of the students are familiar with the words 
given, and that is why I think the game is useful to introduce them to the new words (see for example Alfirrević, 2015 and Silsüpür, 2017).

Table 3. List of verbs for the Gest-Guess

\begin{tabular}{llll}
\hline 1. & to walk & 8. & to swim \\
2. & to sleep & 9. & to talk \\
3. & to open & 10. & to walk \\
4. & to cry & 11. & to give \\
5. & to smile & 12. & to hear \\
6. & to write & 13. & to run \\
7. & to read & 14. & to jump \\
\hline
\end{tabular}

Table 4. List of adjectives for the Unscramble It

\begin{tabular}{llll}
\hline 1. & sad & 8. & good \\
2. & slow & 9. & happy \\
3. & fast & 10. & easy \\
4. & cold & 11. & bad \\
5. & hot & 12. & smart \\
6. & tall & 13 & low \\
7. & big & 14. & soft \\
\hline
\end{tabular}

Table 5. List of nouns for the Pictionary

\begin{tabular}{llllllll}
\hline \multicolumn{3}{c}{ Group A } & & \multicolumn{3}{c}{ Group B } \\
\hline 1. & kite & 8. & ant & 1. & dice & 8. & pan \\
2. & basket & 9. & knife & 2. & bowl & 9. & window \\
3. & nose & 10. & wall & 3. & ear & 10. & cheek \\
4. & letter & 11. & chin & 4. & envelope & 11. & moon \\
5. & dress & 12. & star & 5. & t-shirt & 12. & nail \\
6. & fridge & 13 & hair & 6. & door & 13 & tail \\
7. & gate & 14. & root & 7. & butterfly & 14. & branch \\
\hline
\end{tabular}

In the tenth week, I had the students learned the English verbs through the Unscramble Verbs plus Motions game and the English nouns through a game called Slam. Both games were adapted from the aforementioned website. In the first game, I wrote a list of scrambled verbs on the board, then I asked each student to unscramble the words (see Table 6). They had to write them on the board, too. When I asked them to unscramble the words, I also acted the words out so that they could quickly recall the words on the board (when they were already known) or memorize them. Those who knew some of the verbs usually said them loudly. However, some other students just learned most verbs for the first time. Therefore, after all words were unscrambled, I asked them to translate each of the verbs written. I intentionally 
gave several types of scaffolds, i.e. acting out, pronouncing and getting students to translate the verbs in the hope that they could easily remember the words.

Table 6. List of verbs for the Unscramble It game

$\begin{array}{llrlll}\text { 1. } & \text { Stop } & 8 . & \text { Put } & 15 . & \text { Wash } \\ \text { 2. } & \text { Write } & 9 . & \text { Type } & 16 . & \text { Grill } \\ \text { 3. } & \text { Pay } & 10 . & \text { Play } & 17 . & \text { Give } \\ \text { 4. } & \text { See } & 11 . & \text { Iron } & 18 . & \text { Ride } \\ \text { 5. } & \text { Cook } & 12 . & \text { Sweep } & 19 . & \text { Watch } \\ \text { 6. } & \text { Grill } & 13 & \text { Mop } & 20 . & \text { Clean } \\ \text { 7. } & \text { Take } & 14 . & \text { Bring } & 21 . & \text { Stop }\end{array}$

For the second game, I had prepared a bag of objects. I asked the students to gather on the yard and stand in a medium circle. I intended to give them an alternative place to study (they can learn outside the class). At the center, I placed the objects on the ground (see Table 7). There were twenty-eight objects that I used. Then I explained the rules of the game in English and in Indonesian. Next, I tried it out once. The students were able to understand the game easily. So, we started the game. I shouted out the word of one of the objects, and they raced to get it. The student who touched it first got to keep the object where he/she stood. The winner was the one who had the most objects at the end of the game. I observed that students did like the game, although they did not know all of the names of the objects. For them, it was more important to participate in the game and had fun together.

Table 7. List of objects for the Slam game

\begin{tabular}{|c|c|c|c|c|c|c|c|}
\hline 1. & Toothpaste & 8. & Mirror & 15. & Plastic glove & 22. & Plastic fork \\
\hline 2. & Toothbrush & 9. & Pen & 16. & Plastic cup & 23. & Plastic spoon \\
\hline 3. & Orange & 10. & Pencil & 17. & Key & 24. & Toy \\
\hline 4. & Lime & 11. & Battery & 18. & Paper & 25. & Umbrella \\
\hline 5. & Cucumber & 12. & Coins & 19. & Envelope & 26. & Hat \\
\hline 6. & Soap & 13 & Napkin & 20. & Wheel & 27. & Bracelet \\
\hline 7. & Box & 14. & Plastic bottle & 21. & Belt & 28. & Pin \\
\hline
\end{tabular}

\section{Some Achievements}

I observed that the English free tutorial had achieved important points. First, it has provided the young students with ample reading texts and vocabulary games that may be different from the teaching techniques at school (e.g. rote learning, drilling, vocabulary exercises). Second, the participants preferred and enjoyed learning vocabulary through games. In most of the meetings, they were happy, enthusiastic and enjoyed the English vocabulary learning. They asked me to always come in the next sessions and give them more games. The rate of the students' presence was around $80 \%$. Third, the English tutorial program was positively appreciated by Bimbel Mita, the parents and the students. The former has permitted me to continue the English tutorial program. Fourth, the small class has made it easier for me to give each student full attention and more chances to play in the games. 


\section{Some Challenges}

There were several challenges during the community service with regard to the techniques and students' ability. First, the students were not accustomed to English pictorial texts. When I asked the students to read and tell what the story was about, most of them told me that they did not understand the content. Then, I asked them to look at the pictures and tell what they thought the story was about. Only one could give a brief summary of the story, the others numbed. Yet, they asked me to learn the words first, and they were ready to note-taking the meanings of the unknown words in Indonesian. To solve the problem, I decided that in the first meeting students could make a vocabulary journal which consisted of a glossary of words they found in the storybooks and their meanings in Indonesian.

Second, the students did not always give a positive reaction for monotonous vocabulary rote-learning through reading texts provided. In the third and fifth weeks, they asked for a game to learn the vocabulary. I assumed that they wanted learning to be fun and different from their daily learning methods at school, which may mostly consist of listening to teachers' explanation, note-taking (I recalled that since the first meeting, the students were always ready with their notebooks and pencils or pens to write down new words without being ordered) and rote learning. Since I believe that learning will best take place in moments when students feel relaxed, and students should be given chances to determine their own learning methods, I had no objection to using games for one or more than one session. Students spontaneously said they enjoyed the game and felt happy learning vocabulary through games.

Third, students of grades 3 and 4 did not seem to be familiar with the simple English sentences. They were more familiar with loose words, especially nouns. In addition, they were not accustomed to the English verbs and adjectives. Therefore, I intentionally gave vocabulary games that highlighted the use of verbs and adjectives. Not all of them liked to write down the new nouns, verbs and adjectives I introduced to them. Consequently, the words should be repeatedly taught through different games so that they would acquire the vocabularies.

Fourth, the space provided for the program was quite limited (because the entire place had to be divided with other groups of students learning other subjects). Students were not able to play some games that require a lot of movements. Besides that, there was no permanent or semi-permanent wall that divides other classes. So, students and teachers across classes can hear and see one another. Consequently, students could not play the games that need a lot of oral interactions, watch videos for learning, listen to songs or other activities that can attract too much attention from students in other groups/classes.

\section{CONCLUSION}

Vocabulary is the door to learning a new language and games is one of the most enjoyable learning techniques. Students enjoyed learning vocabulary through games more than reading pictorial texts. They were happy to learn in ways that are different from what they have at school and to be given chances to show their abilities in each of the game. One of the challenges was to make students acquire new or unfamiliar language aspects such as verbs and adjectives and make them remember what they have learned. Despite the difficulties to learn the new words, the students have consistently shown the eagerness to learn English and the positive feeling that learning can be fun throughout the program.

To deal with the limited space, I suggest that the organizer (Bimbel Mita) consider dividing all the participants into different groups that have a different schedule. For instance, the Math 
group is on Sunday at 8, the Social Science group at 9.30, the English is at 11. The purpose is to have each class maximally use the space and media to aid learning. They may also consider inviting other parties to contribute the learning media such as TV, CD or DVD player, speaker, realia and other objects relevant to the subjects taught. It is commonly known that the traditional teaching method in the classroom lacks real practices for real comprehension, which can be filled in by this tutorial program.

\section{References}

1. Acosta, J. (2013). Easy Stories: People. Retrieved from http://bestofthereader.ca/Ebooks/EasyStories-People.pdf

2. Alfirević, T.M. (2015). The influence of games on English language vocabulary learning of second and third grade elementary school students. Методички видиии, 6(6), 153-170. https://doi.org/10.19090/mv.2015.6.153-170

3. Chou, M. (2012). Assessing English vocabulary and enhancing young English as a Foreign Language (EFL) learners' motivation through games, songs, and stories. Education 3-13, 42(3), 284-297. https://doi.org/10.1080/03004279.2012.680899

4. ESL KidStuff. (2019, July 17). ESL Kids Games \& Activities. Retrieved from https://www.eslkidstuff.com/esl-kids-games/vocabulary-games.htm

5. Graves, M.F., Schneider, S., \& Cathy, R. (2018). Empowering Students with Word-Learning Strategies: Teach a Child to Fish. The Reading Teacher, 71(5), 533-543. https://doi.org/10.1002/trtr.1644

6. Iftanti, E. (2012). A survey of the English reading habits of EFL students in Indonesia. TEFLIN Journal, 23(2), 149-164. http://journal.teflin.org/index.php/journal/article/view/144

7. Lee, L. (1997a). A Packet of Seeds. Selangor, Malaysia: Pelangi Publishing Group.

8. Lee, L. (1997b). Our New House. Selangor, Malaysia: Pelangi Publishing Group.

9. Li, M., \& Kirby, J.R. (2015). The effects of vocabulary breadth and depth on English reading. Applied Linguistics, 36(5), 611-634. https://psycnet.apa.org/record/2015-54845-003

10. Pellicer-Sánchez, A. (2016). Incidental L2 vocabulary acquisition from and while reading. Studies in Second Language Acquisition, 38(1), 97-130.

https://doi.org/10.1017/s0272263115000224

11. Puimège, E., \& Peters, E. (2019). Learners' English vocabulary knowledge prior to formal instruction: The role of learner-related and word-related variables. Language Learning, 69(4), 943-977. https://doi.org/10.1111/lang. 12364

12. Silsüpür, B. (2017). Does using language games affect vocabulary learning in EFL classes?. Journal of Foreign Language Education and Technology, 2(1), 83-104. http://jflet.com/jflet/index.php/jflet/article/view/26

13. Smith, S.A., \& Murphy, V.A. (2015). Measuring productive elements of multi-word phrase vocabulary knowledge among children with English as an additional or only language. Reading and Writing, 28(3), 347-369. https://doi.org/10.1007/s11145-014-9527-y

14. Wells, J.C., \& Narkon, D.E. (2011). Motivate students to engage in word study using vocabulary games. Intervention in School and Clinic, 47(1), 45-49.

https://doi.org/10.1177/1053451211407493 